\title{
Assessing Pre-Service Teachers' Understandings Of The Nature Of Scientific Knowledge Via Media Reports
}

\author{
Nagihan İMER ÇETIN*
}

\author{
Esra MACAROĞLU AKGÜL**
}

\begin{abstract}
This study aims to examine the usability of media reports as an alternative technique to assess how preservice teachers' understandings on the characteristics of scientific knowledge differ in a presented media reports. Fifty pre-service mathematics teachers, who were enrolled in department of teaching mathematics at the secondary level, participated in this research study. Media reports were used to assess participants' understandings of the nature of scientific knowledge. Data were analyzed by open coding and the codes were categorized to determine conceptual constructs. Analysis of qualitative data gathered via media reports revealed that pre-service teachers hold inadequate understanding about the nature of scientific knowledge.
\end{abstract}

Keywords: Nature of Science, Media Reports, Pre-service Teachers, nature of scientific knowledge.

\section{Öğretmen Adaylarının Bilimsel Bilginin Doğası Hakkındaki Anlayışlarının Medya Haberleri Aracılığıyla Değerlendirilmesi}

Özet

Bu çalışmanın amacı medya haberlerinin öğretmen adaylarının bilimsel bilgi hakkındaki anlayışlarını değerlendirmede alternatif bir ölçme aracı olarak kullanılabilirliğini incelemektir. Çalışmanın örneklem grubunu 50 matematik öğretmen adayı oluşturmuştur. Katılımcıların bilimsel bilginin doğası hakkındaki görüşlerini değerlendirmek için medya haberleri kullanılmıştır. Çalışmadan elde edilen veriler kodlanmış ve elde edilen kodlar kategorize edilerek kavramsal yapılara ulaşılmıştır. Medya raporlardan elde edilen nitel verilerin analizleri, öğretmen adaylarının bilimsel bilginin doğası hakkında yetersiz görüşe sahip olduklarını ortaya koymuştur.

Anahtar Kelimer: Bilimin doğası, medya haberleri, öğretmen adayları, bilimsel bilginin doğası.

* Koç Üniversitesi, İnsani ve Edebi Bilimler Bölümü, nagihanimer@gmail.com

** Prof. Dr., Yıldız Teknik Üniversitesi, macaroglu yildiz.edu.tr 


\section{INTRODUCTION}

Science is an important tool for citizens to construct comprehensive understanding of the world around them and discovering what natural world is and how it works rather than a collection of isolated and static facts listed in a textbook (BSCS, 2008). Therefore, science cannot be considered in isolation from socioscientific issues in everyday life so that a scientifically literate person should be capable of understanding and interpreting how science works. Citizens are required to learn and understand science in depth for being scientifically literate. Scientific literacy is the focus of science curriculum and can be defined as; being aware of issues and its effects to lives, thinking scientifically and using scientific knowledge and processes to both interpret how science works and to interpret the reliability of scientific claims in personal and public decision making (Millar and Osborne; 1998; National Research Council [NRC], 1996). Roberts (1995) identifies scientific literacy as having a variety of skills, including expressing wonder and asking questions about world, formulating hypotheses, carrying out research, and evaluating evidence and conclusions. Definitions of scientific literacy can be vary but all of them indicate that scientific literacy is fundamental for making decisions as well as participation in public policy debates about social and economic issues (Cakmakci and Yalaki, 2012). Having adequate level of scientific literacy allows each of citizens to become lifelong learners (Erdoğan and Köseoğlu, 2012).

In order to become scientifically literate, nature of science should be understood and learned in a significant way by all students, because nature of science is essential and critical component of scientific literacy (Bell and Lederman, 2003). Although there is no consensus on universally accepted definition of nature of science
(NOS) among scientists, in general, it includes understanding the unique aspects of scientific knowledge and scientific ways of knowing (Cobern and Loving, 2000; Lederman, 1992; Roberts, 2007). Abd-El-Khalick and Lederman (2000, p.1063) emphasize the characteristics of scientific knowledge such as followings:

\section{Scientific knowledge is}

(a) Tentative (subject to change);

(b) Empirically-based (based on and/or derived from observations of the natural world);

(c) Subjective (theory-laden);

(d) Partially based on human inference, imagination, and creativity;

(e) Socially and culturally embedded;

(f) Subject to a distinction between observations and inferences; and

(g) Subject to distinctions between the functions of theories and laws.

These aspects of scientific knowledge needs to be taught to students in the science education contexts, so that the students will become more critical consumers of the scientific knowledge that is involved in their lives in many ways (Howe, 2009). It is important to educate students as scientifically literate citizens. Developing critical thinking skills in students will help them be wise consumers of scientific information. Training students in such habits will give them a chance to have life skills they need to thrive in the world. But before doing so, it is important to examine existing views of the nature of science held by students, teachers, or teacher candidates, in all levels. Especially it is crucial for teachers and teacher candidates because teachers' behaviors, thoughts and beliefs, especially their beliefs and knowledge about the nature of science, influence their classroom practices directly or indirectly 
(Palmquist and Finley, 1997) and it is not possible for teachers to teach what they do not know (Abd-El-Khalick and Lederman, 2000; Lederman and Zeidler, 1987). Thus, there is a significant relationship between teachers' knowledge of nature of science and their teaching role (Özdemir, 2007).

- How do pre service math teachers understand and identify scientific knowledge?

\section{METHOD}

\section{Participants}

Having adequate views regarding the nature and function of science is important for science and mathematics instruction (NRC, 1996). Thus, mathematic teachers, not only science teachers, should guide their students' enterprise to develop more appropriate understanding about the nature of science (Aktamis, 2012). For this reason, pre service math teachers were choosen as a sample group for this study. This study conducted in Istanbul, Turkey at teacher training institution (a university faculty) at the end of spring semester Fifty pre-service mathematics teachers, including twenty-one females and twenty-nine males who are senior students enroll in department of secondary mathematic teaching were surveyed in this study.

\section{Data Analyses}

Media reports were used for assessing preservice math teachers' understandings about the nature of scientific knowledge. Firstly, researchers selected media reports from different daily newspapers without evaluating them in terms of including scientific knowledge. While selecting media reports researchers considered news to be short not too long for keeping students motivation. Researchers categorized media reports into two groups; scientific and non-scientific. But while categorizing media reports as scientific, researchers considered them to include at least one of the characteris- tics of scientific knowledge. After getting media reports, five media news which were not related to the science content and five science related media news, in total ten media news were pasted to each poster. Then, each group was given a poster including ten media news on it.

\section{Experimental Procedure}

In the experimental procedure participants were grouped into five; therefore, 10 groups of participants were formed. Then, each group was given a poster including ten media news on it. Researchers distributed the posters randomly to groups. Pre-service teachers were asked to evaluate the media reports on their posters for being scientific or not being scientific. Additionally, participants were asked to write their reasoning about "being scientific" or "not being scientific" for the reports. In other words, they were asked to list their criteria for a media report to be scientific or not to be scientific.

\section{Data Analyses}

Qualitative methods were used to follow up on analysis of data collected in this research (Hewson \& Hewson, 1989). The purpose of qualitative research is not testing hypothesis or making generalizations. It is used for analyzing the data to bring order and giving meaning to collected data (Bogdan and Biklen, 1992). The first step of the qualitative analysis is the "coding of the data". For this, the essays written by pre-service teachers were broken down into pieces to examine in depth. In other words, data were analyzed word by word. Then, participants' each statement was assigned with a number for coding. The second stage of the data analysis is to develop "themes". In this step, we grouped the similar codes into themes based on their common properties. For example, participants' statements regarding charac- 
teristics of scientific knowledge were grouped together. Themes were used to form assertions.

\section{FINDINGS}

Following assertions are created through themes.

Assertion 1: $55 \%$ of pre-service teachers described media reports as scientific if it involves scientific method. It was seen that they used the words "scientific method" and "scientific process" interchangeably. Participants claimed that there is a universal scientific method which is a stepwise procedure that scientists follow. The following quote illustrates this view:

"This media report is scientific because it includes the steps which are defining the problem, research questions, collecting data and developing hypothesis and results..."

Another example entitled "Support the Development of Education in Portage":

"....This report was investigated by experts on the subject and outcomes of the study were presented in a scientific way such as asking questions, formulating hypothesis, collecting data,presenting results so this report is scientific..."

Teachers' interpretation regarding media reports entitled "Blind British Sees via His Teeth" is as follows:

"...scientific process in this report is being presented; also it is an article which helps the development of medical field..."

Another group of teachers' views about scientific knowledge regarding the media report entitled "Vaccine is Ready for Swine Flu" is as follows:

"It was occurred as a result of scientific progress and knowledge. Also this report was supported by samples so it is scientific."

"This report is scientific because it was gained from observation, measurement and experiment..."
$40 \%$ of pre-service teachers labeled the report as a non-scientific due to the fact that scientists didn't follow a single, universal scientific method which done by step by step that start first with observation then experiment etc.

"Report entitled 'Flu of ' $A$ ' affects half of the Population' is not scientific knowledge. It didn't inform about the content of the disease just the public and sanitation were warned against the spread of the disease. It doesn't mention about any scientific process as making observation, doing experiment etc. so it isn't scientific."

Assertion 2: $60 \%$ of pre-service teachers in this study agreed with the model on the observational and experimental aspect of the nature of scientific knowledge. They characterized media reports as a scientific knowledge whether it involves observation and experiment. The following quote supports this perception of teachers about media report entitled "Talk Before Sleep Not Read Fairy Tales":

"...it is scientific. Result of the experiments showed a positive effect on children speech..."

Another media report entitled "Eight New Butterfly Species in Hatay" was interpreted as a scientific knowledge. Teachers stated about that media report as follows:

\section{"...it is scientific. The increases of the number of butterflies were seen as a result of observation. \\ Evolution of new species was observed..."}

A group of teachers identified the media report entitled "How to Get Rid of Mites" as a scientific. Following quote explains why teachers think it is a scientific.

“...it is scientific because mite's life cycle was observed and information was given about the causes and consequences of the disease..."

As can be seen in each of the examples above, the most common criteria of scientific knowledge for teachers was that scientific 
knowledge must require observation and experiment. $60 \%$ of teachers believed that it is enough for scientific knowledge to base on just only observation or experiment.

Assertation 3: On the other hand, another interesting finding was the fact that $10 \%$ of the participants considered the media report as scientific if it was carried out by scientific and technological research council such as TUBITAK. Example is as follows:

"....this report is scientific because it is a research conducted by Tübitak. 247 researchers participated in this study..."

Assertation 4: A group of participants (25\%) indicated that media report was scientific if it was carried out by scientist. The following quotation illustrates this view:

"We can assert this media report entitled 'Turkish Scientist is the First for inventing Artificial Intelligence Robot" as a scientific because it was invented by scientist also the machine can facilitate the lives of people".

Assertation 5: Moreover, as soon as some of the participants (20\%) read the term "technology" in media report, they associated it with scientific knowledge. It is obvious that they believe that science and technology are same kind of knowledge and they are only separated in terms of technology is more of an applied science. Additional evidence of this novice view comes from a group of teachers:

“.... report entitled 'Electronic Nose Smells Wine' is scientific because this media report includes technology and developments in technology..."

Assertation 6: Some of the participants (10\%) expressed media reports as a scientific just only media report contains graphic and statistical data. Below are quotations that support this assertation:
"Report entitled 'Nabucca Reached to a Happy Ending: Signature in Ankara on July 13' is scientific because firstly, it is quantitative information and also it was supported by graphics."

"This report has results. Also, graphics and tables were presented as a result of investigation, for this reason it is scientific."

Assertation 7: The most frequent response given by pre-service teachers $(70 \%)$ is the importance of scientific content. But none of them explained what they wanted to mean by "scientific content" in details. Below are quotations from different respondents:

"A report entitled "Russia and Turkey Agreed to Establish a Working Group on Implementation of the Blue Stream-2 Project" is non-scientific due to

that it does not include any scientific content. It contains some interpretations of countries about the issue, so this report isn't scientific knowledge."

Assertation 8: Some group of the pre-service teachers $(30 \%)$ characterized the media report as a non-scientific because of the fact that it wasn't supported by enough evidence and it wasn't generalized.

"When looking first the title of the report, it seems as though it is scientific, but when reading the content of the report, you realized that it was constructed upon only USA due to the fact that it doesn't generalized for all. So it isn't scientific."

\section{RESULTS}

This study show parallel results with other researches done by same purpose that preservice teachers hold inadequate understandings about the nature of scientific knowledge (Kucuk, 2008; Dogan-Bora, 2005; Tasar, 2005). From the analyses of media reports, it was seen in assertion 1 that most of participants believed that there should be a scientific method which is major criteria for scientific knowledge. Also, 
they seemed to believe that all scientists follow step-by-step scientific method. Thus, participants have naive views with regard to how scientific knowledge develops. This finding is parallel with the finding of Kilic, Sungur, Cakıroglu and Tekkaya (2005). On the other hand they appreciated the role of observation in scientific process but they didn't mention about human imagination and creativity in this process. Lederman (1992) indicated that even though scientific knowledge is derived from observations, it involves human imagination and creativity. More than half of the students (60\%) emphasized the experimental aspect of scientific process as an essential part of it. They thought a study cannot be scientific without an experiment.

Participants (10\%) naively indicated that if science is conducted by a scientific research council like TUBITAK, it is scientific. However, a group of participants (25\%) associated scientific knowledge with scientists. In fact, science is open to everyone who is wondering about the world and wants to know how the world works. Results show that the word "technology" brings to pre-service teachers' mind science. Participants (20\%) associated technology with science as soon as they see "technology" word on the media report. From this assertation an implication can be drawn that preservice teachers believed that technology and science are the same kind of knowledge whereas they are not same kind of knowledge and technology is not always application of science.

As to the criteria for non- scientific knowledge, pre-service teachers stressed confusing responses. A great deal of them mentioned about the scientific content for being scientific knowledge. But, they didn't describe the mean- ing of scientific content. It might be due to that participants aren't aware of the aspects of nature of science so they characterized the media report as non-scientific if it isn't include scientific content. This shows that it is a way of escape for participants to describe what nonscientific is. Many responses to the criteria for non-scientific knowledge relate to the role of evidence and generalizability in science.

\section{DISCUSSION AND CONCLUSION}

In this study, media reports were used as an alternative technique to assess pre-service math teachers' understandings of the nature of scientific knowledge and it is showed that media reports can be used as an effective assessment tool to be informed about learners scientific literacy. Determining learners' especially preservice or in-service teachers' conceptions about nature of scientific knowledge is essential due to effective teaching skills for teachers because teachers are trainers of students who are representative of future. Not only science teachers but also math teachers should be aware of how science works because it is important for math teachers to have adequate views concerning nature of science for understanding the essence of mathematics. When looking history of science, we see that Leonardo da Vinci mentioned about the importance of experimental science in mathematics. $\mathrm{He}$ claimed that theory and practice should be associated with each other; practice without theory is meaningless. On the other hand theory with no practice is meaningless (Aktamis, 2012; Yildirim, 2008). For this reason, it is important for math teachers to have informed understandings about nature of scientific knowledge.

\section{References}

Abd-El-Khalick, F. \& Lederman, N. G. (2000). The influence of history of science courses on students' views of nature of science. Journal of Research in Science Teaching, 37, 1057-1095. 
Aikenhead, G., Ryan, A., \& Desautels, J. (1989). Monitoring students views on Science-TechnologySociety issues: The development of multiple choice items. Paper presented at the annual meeting of the National Association for Research in Science Teaching, 34, 39-55.

Aktamış, H. (2012). How prospective mathematics teachers view the nature of science. Procedia - Social and Behavioral Sciences, 31, 690-694

Bell, R.L., \& Lederman, N.G. (2003). Understandings of the nature of science and decision making in science and technology based issues. Science Education, 87 (3), 352-377.

Biological Sciences Curriculum Study (BSCS). 2008. Scientists in Science Education. Colorado Springs: BSCS. Retrieved from (http://science.education.nih.gov/sise)

Bogdan, R.C. \& Biklen, S.K. (1992). Qualitative research for education: an introduction to theory and methods, 2d ed. Boston, MA: Allyn \& Bacon.

Cakmakci, G. \& Yalaki, Y. (2012). Promoting student teachers' ideas about nature of science through popular media. Trondheim, Norway: S-TEAM/NTNU.

Carey, S., \& Smith, C. (1993). On understanding the nature of scientific knowledge. Educational Psychologist, 28 (3), 235-251.

Clough, M. P. (2007). Teaching the Nature of Science to Secondary and Post-Secondary Students: Questions Rather Than Tenets. Journal of Science Education, 8(2), 31-40.

Cobern, W. W. and Loving, C. C. (2001), Defining "science" in a multicultural world: Implications for science education. Science Education, 85 (1), 50-67.

Dogan-Bora, N. (2005). Investigating science teachers' and high school students' views on the nature of science in Turkey. PhD Thesis, Ankara: Gazi University. Ankara, Turkey.

Erdoğan, M. N. \& Köseoğlu, F. (2012). Analysis of High School Physics, Chemistry and Biology Curriculums in terms of Scientific Literacy Themes. Educational Sciences: Theory \& Practice (ESTP), 12 (4), 2889-2904.

Golabek, C. \& Amrane-Cooper, L.,(2011). Trainee teachers' perceptions of the Nature of Science and implications for pre-service teacher training in England. Research in Secondary Teacher Education, 1 (2), 9-13.

Hazen, R. (2002). Why should you be scientifically literate? New Frontiers: ActionBioscience.org.

Holbrook, J. \& Rannikmae, M. (2007). Nature of Science Education for Enhancing Scientific Literacy. International Journal of Science Education, 29 (11) 1347-1362.

Howe, E.M. (2009). Henry David Thoreau, forest succession, and the nature of science: A Method for curriculum cevelopment. The American Biology Teacher 71(7), 397-404.

Kılıç, K., Sungur, S. Çakıroglu, J. \& Tekkaya, C. (2005). Ninth grade students' understanding of the nature of scientific knowledge. Hacettepe University Journal of Education Faculty, 28, 127-133.

Kucuk, M. (2008). Improving Preservice Elementary Teachers' Views of the Nature of Science Using Explicit-Reflective Teaching in a Science, Technology and Society Course. Australian Journal of Teacher Education, 33(2).

Lederman, N.G. (1992). Students' and teachers' conceptions of the nature of science: A review of the research. Journal of Research in Science Teaching, 29 (4), 331-359.

Lederman, N. G., \& Zeidler, D. L. (1987) science teachers' conceptions of the nature of science: Do they really influence teaching behavior? Science Education, 71(5), 721-734.

Liang L., Chen S., Chen X., Kaya O., Adams A., Macklin M. \& Ebenezer, J. (2009). Preservice teachers' views about Nature of Scientific knowledge development: An international collaborative study. International Journal of Science and Mathematics Education, 7, 987-1012 
Liu, S. \& Lederman N. (2007). Exploring prospective teacher's worldview and conceptions of the Nature of Science. International Journal of science Education, 29 (10), 1281-1307

Martin-Diaz, M. (2006).Educational background, teaching experience and teachers' view on the Inclusion of the Nature of Science in the Science curriculum.International Journal of science Education, 28 (10) 1161-1180.

Millar, R., \& Osborne, J. F. (Eds.). (1998). Beyond 2000: Science Education for the Future. London: King's College London.

National Research Council. (1996). National science education standards . Washington, D.C.: Author.

Özdemir, G. (2007). The effects of the nature of science beliefs on science teaching and learning. Uludağ Üniversitesi Eğitim Fakültesi Dergisi, 20 (2), 355-372.

Palmquist, B. C., \& Finley, F. N. (1997). Pre-service teaches' views of the nature of science during a postbaccalaureate science-teaching program. Journal of Research in Science Teaching, 34(6), 595-615.

Roberts, P. (1995). Defining Literacy: Paradise, Nightmare or Red Herring, British Journal of Educational Studies, 43 (4), 412-430.

Roberts, D. A. 2007. Scientific literacy/science literacy. In Handbook of research on science education, eds. S. Abell and N. G. Lederman, 729-780. Mahwah, NJ: Lawrence Erlabaum Associates.

Ryder, J. (2001). Identifying science understanding for functional scientific literacy. Studies in Science Education, 35, 1-44.

Tairab, H. H. (2001). How do Pre-service and In-service Science Teachers View the Nature of Science and Technology?. Research in Science \& Technological Education, 19 (2), 235-250.

Tasar, M.F. (2005). Probing preservice teachers' understandings of scientific knowledge by using a vignette in conjunction with a paper and pencil test. Eurasia Journal of Mathematics, Science \& Technology Education, 2(1), 53-70.

Yıldırım, C. (2008). Bilim Tarihi, Remzi Kitabevi, 11. Edition, Istanbul, Turkey. 